\title{
A Hypoxia-Sensitive Zwitterionic Vehicle for Tumor-Specific Drug Delivery Through Antifouling-Based Stable Bio-Transport Alongside PDT-Sensitized Controlled Release
}

Tingjie Yin ${ }^{1, *}$, Xuxin Chu ${ }^{1}$, Jiejie Cheng, Jinlai Liang, Jianping Zhou, Meirong Huo*

†State Key Laboratory of Natural Medicines, Department of Pharmaceutics, China Pharmaceutical University, 639 Longmian Avenue, Nanjing 211198, China

${ }^{1}$ Tingjie Yin, Xuxin Chu contributed equally to this work.

\section{SUPPLEMENTARY RESULTS}
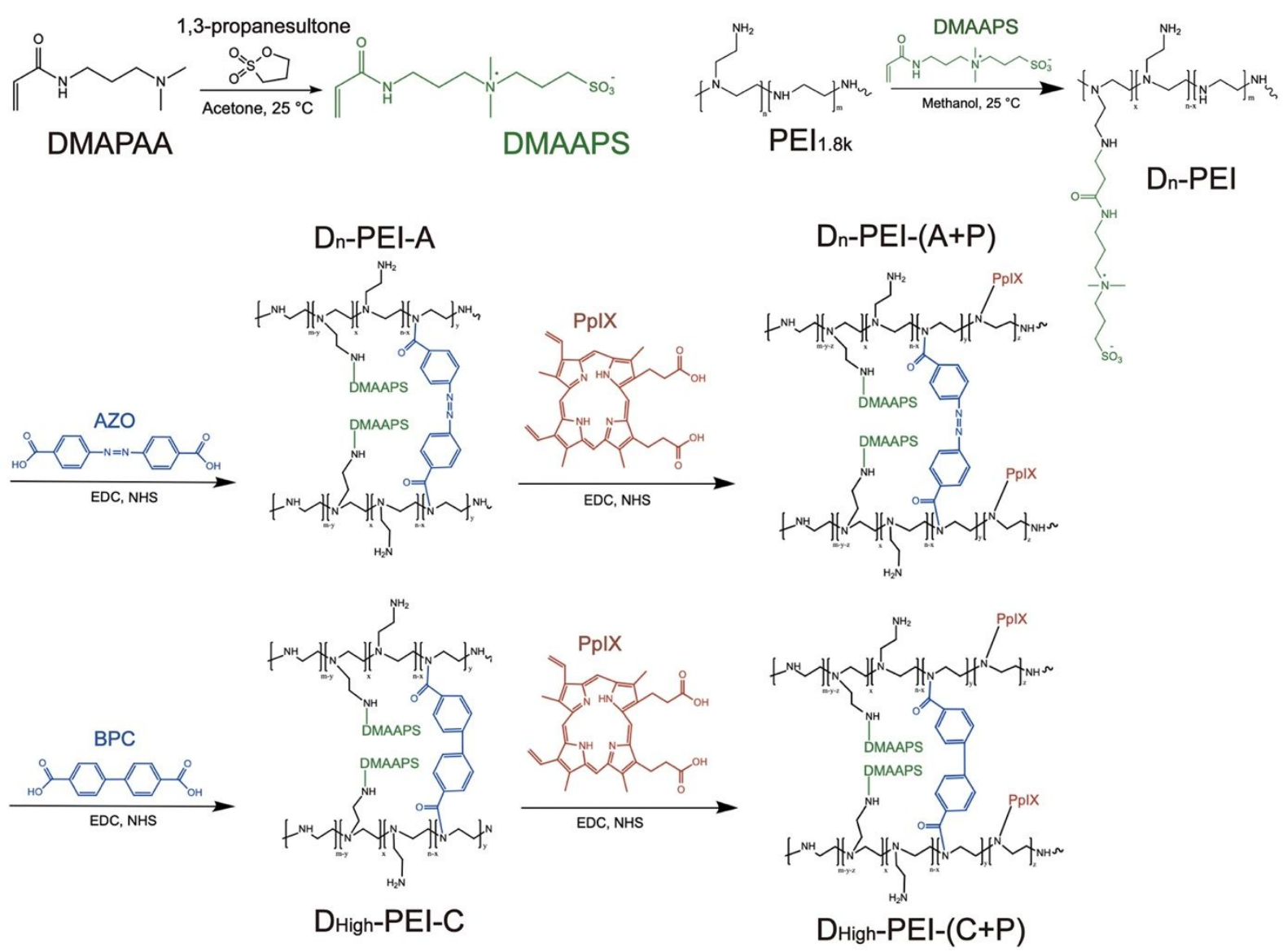

Figure S1. The synthetic scheme of $\mathrm{D}_{\mathrm{n}}-\mathrm{PEI}-(\mathrm{A}+\mathrm{P})$ and $\mathrm{D}_{\mathrm{High}}-\mathrm{PEI}-(\mathrm{C}+\mathrm{P})$ conjugates. 


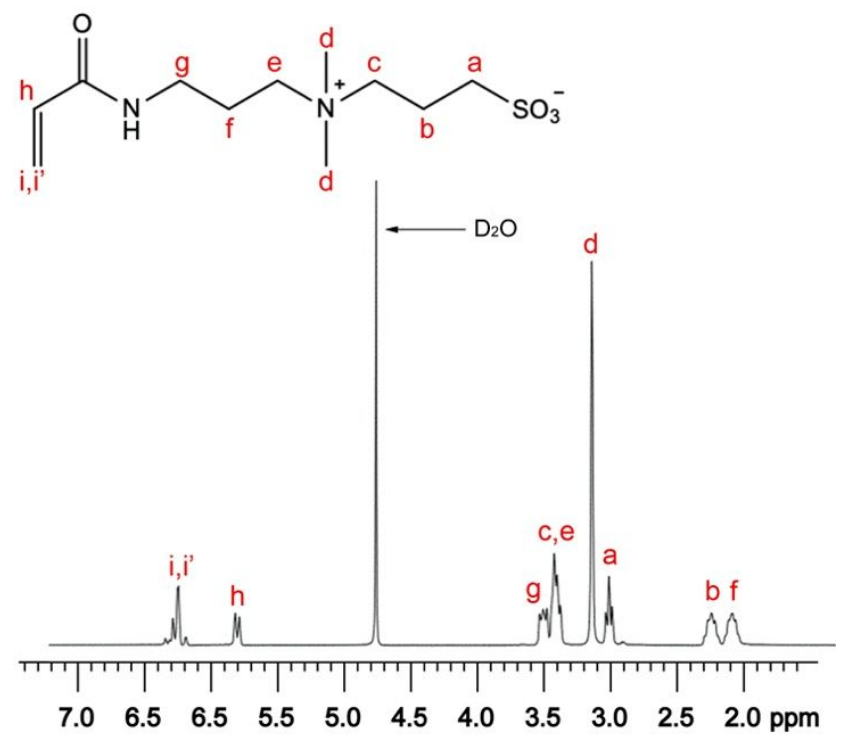

Figure S2. ${ }^{1} \mathrm{H}$ NMR spectra of DMAAPS with the solvent of $\mathrm{D}_{2} \mathrm{O}$.

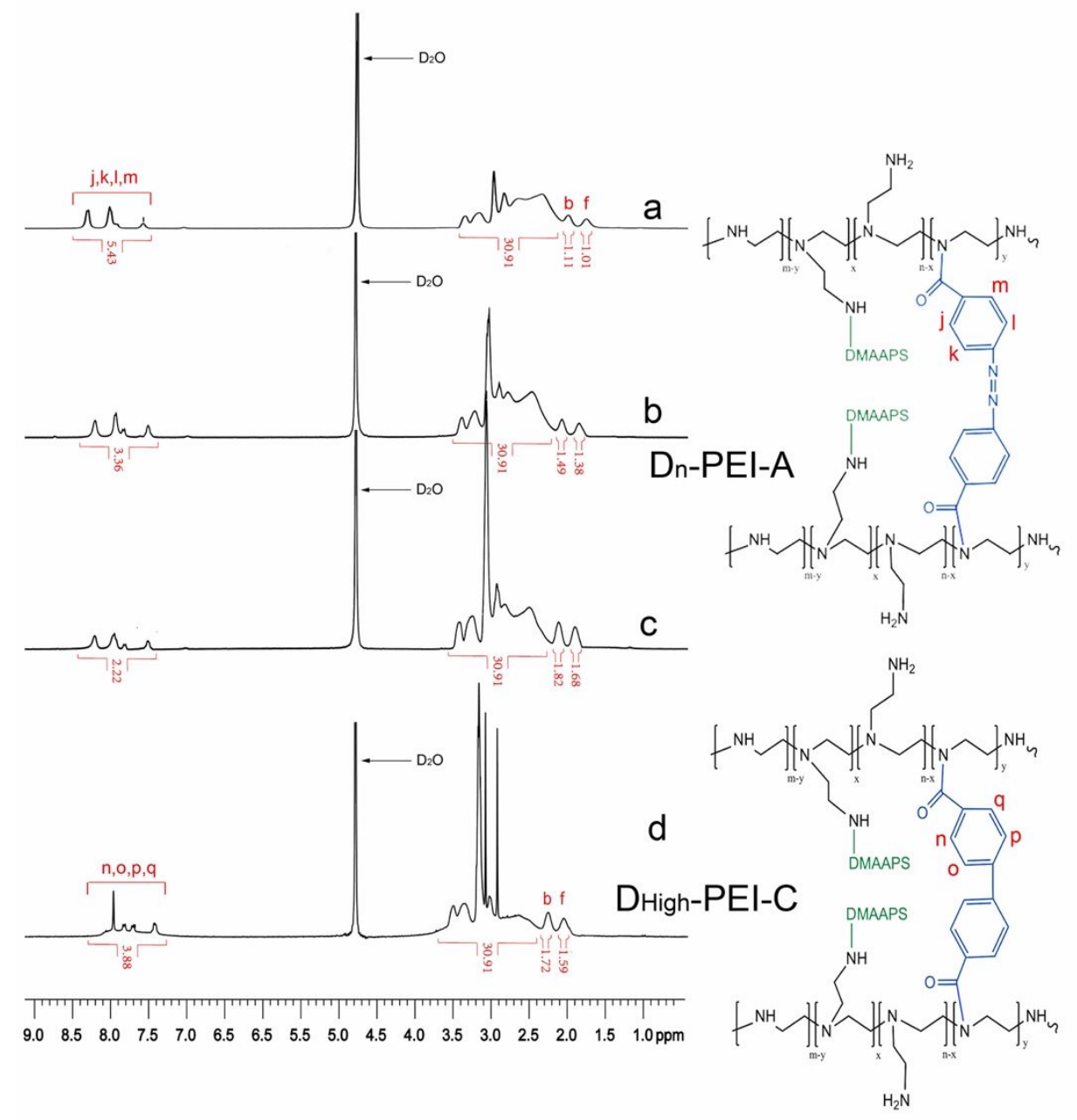


Figure S3. ${ }^{1} \mathrm{H}$ NMR spectra of $\mathrm{D}_{\text {Low }}-\mathrm{PEI}-\mathrm{A}$ (a), $\mathrm{D}_{\text {Middle }}$-PEI-A (b), $\mathrm{D}_{\mathrm{High}}$-PEI-A (c) and $\mathrm{D}_{\mathrm{High}}-\mathrm{PEI}-\mathrm{C}$ (d) with the solvent of $\mathrm{D}_{2} \mathrm{O}$.

\section{Methods for Figure S4}

The intravenous safety of the designed nanoassemblies was also evaluated by the hemolysis experiment. The fresh blood was collected from rats to prepare blood cell suspension. The blank nanoassemblies $(0.125-1.5 \mathrm{mg} / \mathrm{mL}$ of materials) and PTX-loaded nanoasseblies $(100-800 \mu \mathrm{g} / \mathrm{mL}$ of PTX) were incubated with the blood cell suspension at $37^{\circ} \mathrm{C}$ for $1 \mathrm{~h}$, following centrifuged at $3000 \mathrm{rpm}$ for $10 \mathrm{~min}$. The absorbance of the supernatant from each sample $\left(\mathrm{A}_{\text {sample }}\right)$ was measured at $540 \mathrm{~nm}$ with a microplate reader $(\mathrm{EL} \times 808$, BioTek instruments, USA). The hemolysis was calculated according to the following formula:

$$
\text { Hemolysis }(\%)=\left(\mathrm{A}_{\text {sample }}-\mathrm{A}_{0 \%}\right) /\left(\mathrm{A}_{100 \%}-\mathrm{A}_{0 \%}\right) \times 100 \%
$$

where $\mathrm{A}_{100 \%}$ and $\mathrm{A}_{0 \%}$ represent the absorbance of the supernatant based on water and saline control group, respectively.
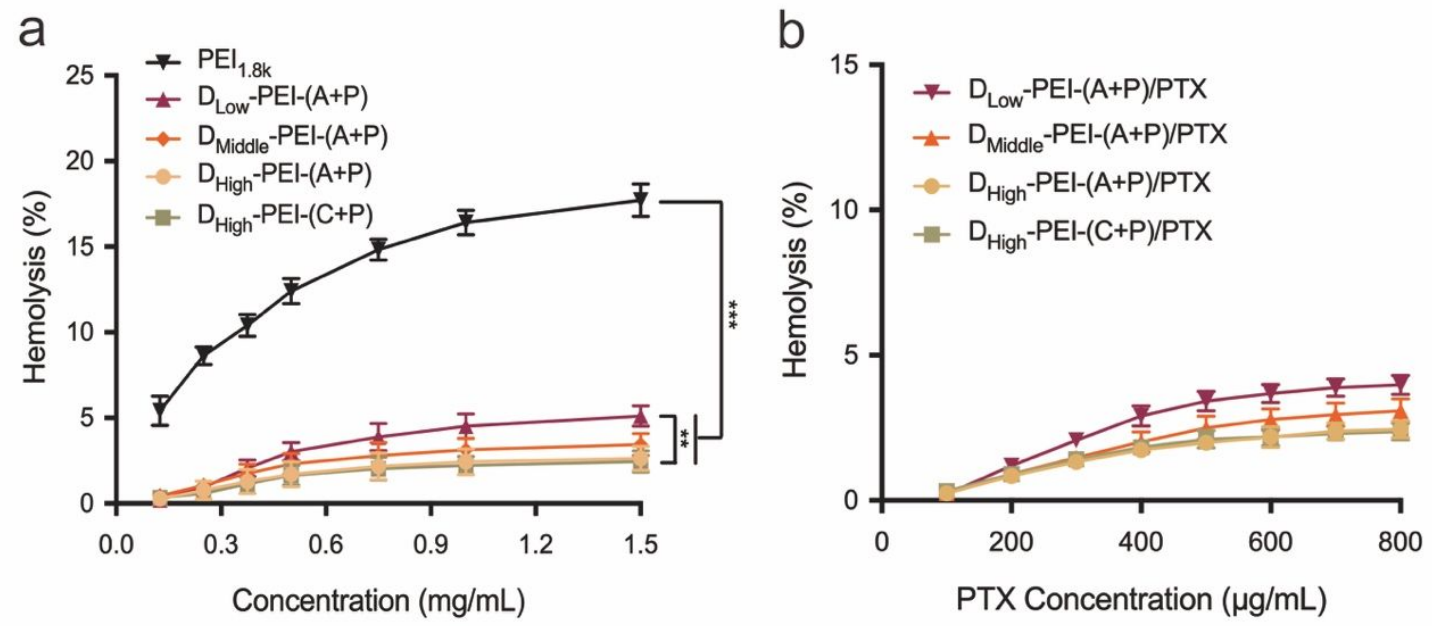

Figure S4. Hemolysis of $\mathrm{D}_{\mathrm{n}}-\mathrm{PEI}-(\mathrm{A}+\mathrm{P})$, $\mathrm{D}_{\mathrm{High}}-\mathrm{PEI}-(\mathrm{C}+\mathrm{P})$ (a) and $\mathrm{D}_{\mathrm{n}}-\mathrm{PEI}-(\mathrm{A}+\mathrm{P}) / \mathrm{PTX}, \mathrm{D}_{\mathrm{High}}-\mathrm{PEI}-$ $(\mathrm{C}+\mathrm{P}) / \mathrm{PTX}(\mathrm{b})$ nanoassemblies. Results were expressed as the mean \pm S.D. $(\mathrm{n}=3) .{ }^{*} P<0.01$, $* * * P<0.001$. 


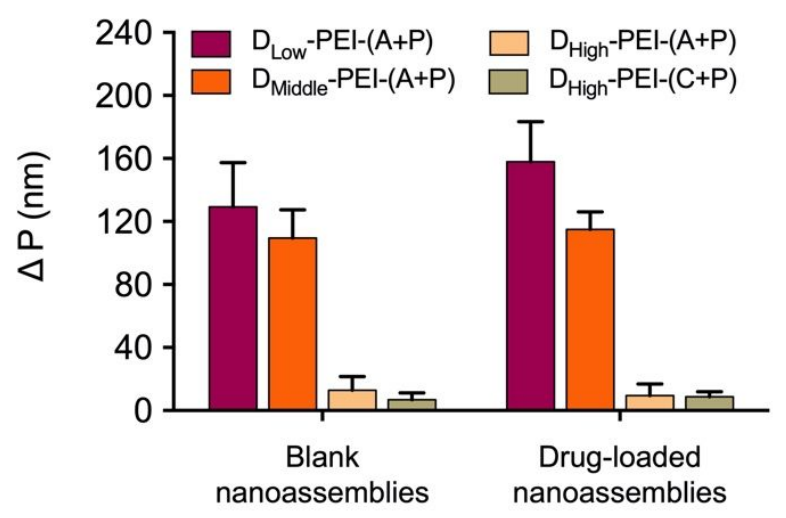

Figure S5. Particle size change of $\mathrm{D}_{\mathrm{n}}-\mathrm{PEI}-(\mathrm{A}+\mathrm{P})$, $\mathrm{D}_{\mathrm{High}} \mathrm{PEI}-(\mathrm{C}+\mathrm{P})$ and $\mathrm{D}_{\mathrm{n}}-\mathrm{PEI}-(\mathrm{A}+\mathrm{P}) / \mathrm{PTX}, \mathrm{D}_{\mathrm{High}}{ }^{-}$ PEI-(C+P)/PTX nanoassemblies after incubation with $10 \%$ serum for $2 \mathrm{~h}$. Results were expressed as the mean \pm S.D. $(\mathrm{n}=3)$.

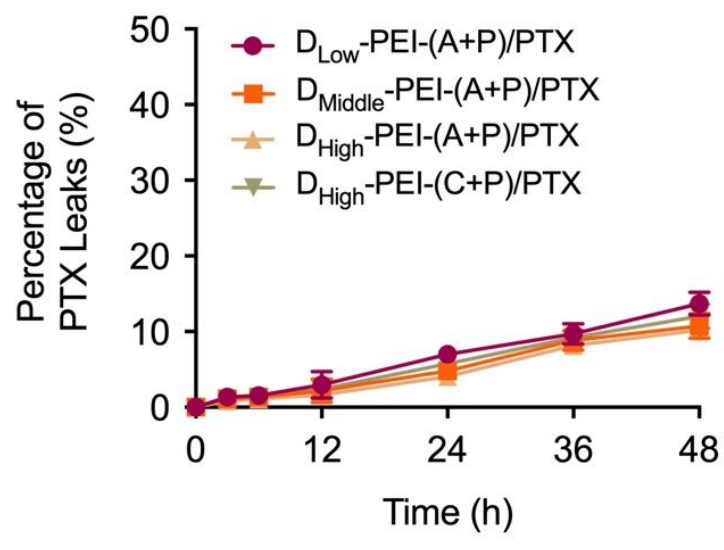

Figure S6. Percentage of PTX leaks from drug-loaded nanoassemblies within $48 \mathrm{~h}$ in the presence of $10 \%$ serum. Results were expressed as the mean \pm S.D. $(n=3)$. 